\title{
Digital Marketing dan Hedonisme Dalam Pengambilan Keputusan Pembelian
}

\author{
I Putu Lugra Agusta Pranawa ${ }^{(1)}$ \\ Agus Putu Abiyasa ${ }^{(2)}$ \\ Bali Tree House ${ }^{(I)}$ \\ Universitas Pendidikan Nasional ${ }^{(2)}$ \\ agus.lugra@gmail.com ${ }^{(I)}$ \\ abiyasa@undiknas.ac.id ${ }^{(2)}$
}

\begin{abstract}
This study discusses digital marketing strategies and hedonism on purchasing decisions. The research location was conducted at the Bali Tree House. The sampling technique uses purposive sampling technique, data collection techniques used are: observation, documentation, and interviews, with the validity method of triangulation data. The results found are as follows: Rumah Pohon Bali has used a digital marketing strategy using Ecommerce, blogs, and social media for digital marketing optimization. Hedonism combined with digital marketing with visual summaries can increase consumer attractiveness. This digital marketing strategy and hedosme can increase purchasing decisions through policy factors and social factors regarding the part of the reference group that is expected to be a strategy that can provide maximum sales results for Balinese tree houses.
\end{abstract}

Keywords: Digital Marketing; Hedonism; Purchasing Decisions

\begin{abstract}
ABSTRAK
Penelitian ini bertujuan meneliti strategi digital marketing dan hedonism terhadap keputusan pembelian. Lokasi pernelitian dilakukann di Bali Tree House. Teknik sampling menggunakan teknik purposive sampling,Teknik pengumpulan data yang digunakan yaitu: obeservasi, dokumentasi, dan wawancara, dengan metode keabsahan data triangulasi. Yang ditemukan hasil sebagi berikut: Bali Tree House telah memanfaatkan Strategi digital marketing dengan pemanfaatan $\mathrm{E}$ - commerce, blog, dan media sosial untuk pengoptimalan pemasaran secara digital. Hedonism yang dikombinasikan dengan digital marketing dengan gambaran visual dapat meningkatkan daya Tarik konsumen. Strategi digital marketing dan hedosme ini dapat meningkatkan keputusan pembelian melalui faktor psikologi dan faktor sosial khususnya pada bagian kelompok referensi sehingga diharapkan strategi ini dapat memberikan hasil penjualan yang maksimal kepada bali tree house.
\end{abstract}

Kata Kunci: Digital Marketing; Hedonisme; Keputusan Pembelian 


\section{PENDAHULUAN}

Perkembangan yang sangat pesat tahun ke tahun semakin cepat dan menimbulkan persaingan pada dunia perhotelan yang sangat pesat (Bali dan Darma, 2019). Berbagai cara dilakukan untuk berlomba lomba meningkatkan tingkat kunjungan (Widana dan Darma, 2018). Perusahaan harus bisa mengincar celah yang tepat dengan mencari tahu apa yang diperlukan dan apa yang diinginkan oleh pasar (Dewi dan Darma, 2019). Dalam persaingan saat ini perusahaan harus memiliki sebuah keunggulan - keunggulan kompetitif. (Darma et. al., 2019; Astuti dan Darma, 2019)

Pada era digital marketing 4.0 yang keseluruhannya menggunakan internet, membuat peluang usaha semakin berkembang dan cepat yang harus ditangkap oleh para pengusaha (Ferdiana dan Darma, 2019). Para pengusaha pada saat ini harus mengikuti arus perubahan, perubahan atau pergeseran keinginan pasar secara tidak langsung akan merubah sebuah model bisnis pada masa ini (Darma, 2019). Perusahaan atau bisnis yang tidak mengikuti perubahan akan tertinggal dan ditinggalkan oleh konsumen mereka, karena keinginan dan prilaku konsumen pun ikut berubah pada era ini. Pemanfaatan digital marketing sangat populer saat ini pemanfaatan media digital sangat membantu dalam memasarkan sebuah produk atau jasa dengan cepat, luas dan murah. Jumlah pengguna internet 2018, sebagai berikut:

Tabel 1.1

Jumlah Pengguna Internet Di Seluruh Dunia

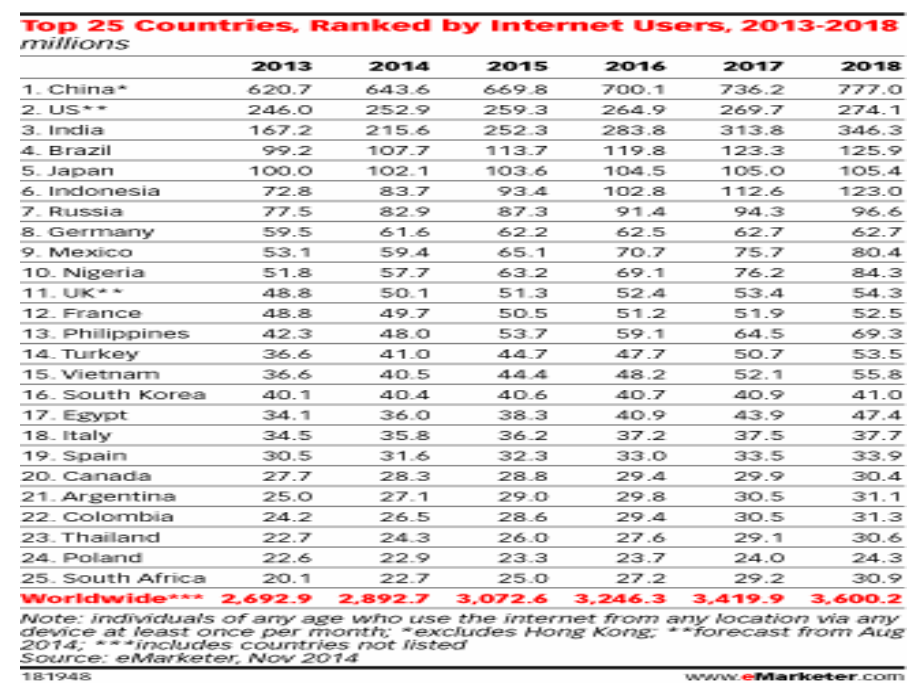

Pengguna internet di dunia pada tahun 2013 sebanyak 2.692.9 (millions) hingga tahun 2018 meningkat menjadi 3.600 .2 (millions) meningkat sebesar 25\% selama 5 tahun. Pengguna internet di Indonesia pada tahun 2013 tercatat mencapai 72.8 juta pengguna internet dan berkembang pada tahun 2018 menajadi 123.0 juta pengguna, pengguna internet berkembang 
sangat pesat di Indonesia hanya dalam waktu 5 tahunsaja dengan meningkat sebanyak 50.2 juta pengguna.

Kekuatan sebuah rekomendasi mulut kemulut dari satu konsumen ke konsumen lain sebuah kegiatan pemsaran yang tidak dapat diatur oleh sebuah pemilik usaha. E- WOM (Electronict Word of Mouth) memiliki sebuah kekuatan yang tidak bisa dikendalikan siapapun dan rekomendasi mulut kemulut sangat ampuh untuk meningkatkan sebuah penjualan dengan waktu yang singkat, karena E- WOM (Electronict Word of Mouth) meningkatkan rasa ingin tahu, meningkatkan minat untuk membeli atau juga dapat mempengaruhi sebuah keputusan pembelian dengan rekomendasi yang diberikan oleh konsumen yang sudah pernah membeli produk atau jasa pada suatu perusahaan (Darma, 2018).

Keputusan pembelian adalah salah satu tahap evaluasi dalam melakukan sebuah pemilihan diantara banyak pilihan yang ada. Pada bisnis perhotelan saat ini persaingan yang sangat ketat menyebabkan banyaknya pilihan dan memiliki seluruh fasilitas yang hampir sama dan harga yang sangat bersaing (Supit dan Darma, 2018).

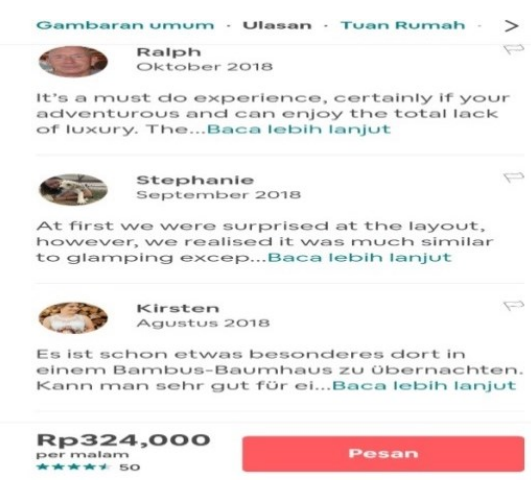

Gambar 1.1

Review Konsumen Bali Tree House di Airbnb

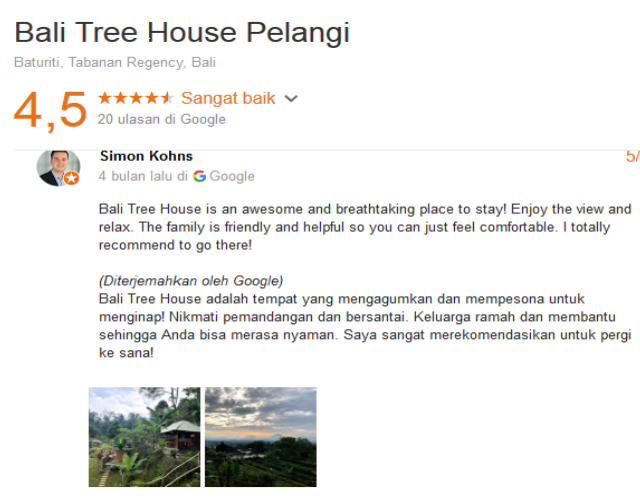

Gambar 1.2

Review Konsumen Bali Tree House di Google 
Dari gambar 1.1 dan 1.2 merupakan review yang dilakukan oleh konsumen bali tree house yang lakukan sebuah E - WOM yang berisikan tentang ungkapan bagaimana kesan mengiap di Bali Tree House. Adanya penyampaian sebuah nilai hedonis melalui sebuah ekspresi dengan menuliskan sebuah reviewe pada sebuah E- Commerce akan menimbulkan model pemasaran baru dengan pemanfaatan nilai hedonis alam atau budaya local yang sudah kurang diminati oleh pasar domistik. Pemanfaatan sebuah platform E - Commerce akan sangat membantu untuk memasarkan sebuah nilai hedonis alam atau budaya local sebagai contoh bali tree house yang hampir dominan tamu yang berasal dari luar Indonesia (Agung dan Darma, 2019)

Menarik untuk diteliti apakah digital marketing yang dilakukan oleh Bali Tree House efektif dalam meningkatkan keputusan pembelian? Dan apakah nilai hedonisme mempengaruhi dan meningkatkan keputusan pembelian Bali Tree House. melihat permasalahan tersebut, maka penulis tertarik untuk melakukan penelitian dengan judul "Digital Marketing Dan Hedonisme Dalam Pengambilan Keputusan Pembelian Konsumen Bali Tree House”. Berdasarkan Latar Belakang Yang Dipaparkan Diatas, Adapun Pokok Permasalahan yang dapat dirumuskan dalam penelitian ini adalah untu mengetahui Bagaimanakah peranan hedonism dan digital marketing dalam meningkatkan keputusan pembelian pada Bali Tree House? Dan Hambatan apa saja yang dialami dalam penggunaan digital marketing untuk meningkatkan keputusan pembelian Bali Tree House?

\section{Digital Marketing}

Digital marketing merupakan sebuah media yang digunakan sebagai platform pembangun brand image suatu perusahaan atau produk dan juga mendukung fungsi penjualan terhadap target konsumen. Penggunaan digital marketing merupakan sebagai cara mempermudah dalam memahami tentang tujuan komunikasi mengenai digital marketing, Morissan (2010) membaginya menjadi : Penyebaran Informasi, Menciptakan Kesadaran, Tujuan Riset, Membangun Persepsi, Percobaan Produk, Meningkatkan Pelayanan, Meningkatkan Distribusi (Putra dan Darma, 2019).

Tujuan dari digital marketing adalah untuk mempertahankan proses komunikasi dengan pelanggan, di mana pelanggan mendapatkan informasi tentang produk, karakteristik, harga dan syarat penjualan. Saat ini promosi melalui internet sangat membantu dan memang perlu untuk menggunakan alat-alat dan inovasi yang tersedia untuk dapat dengan benar menerapkan layanan promosi yang pada akhirnya akan berujung pada keberhasilan bisnis (Darma, 2019). 


\section{E-WOM}

E-WOM sebagai sebuah media komunikasi untuk saling berbagi informasi mengenai suatu produk atau jasa yang telah dikonsumsi antar konsumen yang tidak saling mengenal dan bertemu sebelumnya Gruen dalam Mustikasari (2017) dan didukung dari penelitian dari Dewi dan Darma (2014). Penelitian yang dilakukan oleh Jimenez dan Mendoza dalam Mustikasari (2017), menunjukkan bahwa e-WOM memiliki pengaruh terhadap perilaku konsumen sebelum konsumen memutuskan untuk membeli sebuah produk atau jasa. e-WOM dibagi dalam tiga dimensi Goyette, et al, dalam Poernamawati (2010) yaitu:Intensity, Valence of Opinion, Content.

\section{E-Commerce}

E-Commerce atau Electronic Commerce adalah penjualan atau pembelian barang dan jasa, antara perusahan, rumah tangga, idividu, pemerintah, dan masyarakat atau organisasi swasta lainnya, yang dilakukan melalui computer pada media jaringan Candra Ahmadi (dalam Putra, 2015; Pranata dan Darma, 2014). E-commerce merupakan konsep perdagangan modern yaitu transaksi jual beli dengan menerapkan teknologi informasi dan telekomunikasi untuk keuntungan financial (Shahnaz, 2016; Widani dan Darma, 2019). E-commerce dapat disimpulkan sebagai bidang bisnis modern yang berbasis teknologi yang berupa website yang berbasis toko online yang diperjual belikan tanpa tatap muka terhadap pembeli. Indicator ECommerce (Putra, 2015): Jumlah pilihan, Kenyamanan, Hiburan

\section{Hedonisme}

Produk Hedonis adalah produk yang dikonsumsi dengan perasaan menyenangkan, rasa gembira, bahkan kenyamanan estetika atau sensual sebagai ciri khasnya Hirschamn dan Hoolbrook (dalam Ferrynadewi, 2016). Nilai hedonis merupakan suatu kegiatan pembelian yang didorong dengan perilaku yang berhubungan dengan panca indera, khayalan dan emosi yang menjadikan kesenangan dan kenikmatan materi sebagai tujuan utaman hidup (Bali dan Darma, 2019). Mereka juga menggolongkan motivasi hedonis ke dalam enam kategori Arnold dan Reynolds (dalam Darma, 2014), yaitu: 1). Adventure shopping, Adventure shopping mengarah pada petualangan pembelia. 2). Social shopping, Motivasi pembelian ini mengarah pada suasana kebersamaan konsumen, sahabat, atau pengunjung lain. 3). Gratification shopping, Perasaan tertentu, seperti rasa senang karena berhasil melakukan presentasi, atau tertekan karena sedang mengalami masalah. 4). Idea shopping, Mengarah pada motivasi seseorang untuk mengetahui tren, fashion, dan inovasi terbaru pada saat itu. 5). Role shopping, 
Termotivasi melakukan pembelian untuk orang lain. 6). Value shopping, Mengarah pada motivasi pembelian karena suatu barang sedang dalam progam diskon atau promosi.

\section{Minat Beli}

Minat beli juga dapat diartikan sebagai suatu bentuk pikiran yang nyata dari refleksi rencana pembeli untuk membeli beberapa unit dalam jumlah tertentu dari beberapa merek yang tersedia dalam periode waktu tertentu Schiffman dan Kanuk (Maharani dan Darma, 2018). Menurut Naas (2016) menyatakan bahwa minat adalah sesuatu hasil pengalaman yang tumbuh dan dianggap bernilai oleh individu adalah kekuatan yang mendorong seseorang itu untuk berbuat sesuatu. Ada beberapa indikator yang terdapat pada Minat Beli antara lain Lucas dan Britt (dalam Maghfiroh, 2016): Ketertarikan (interest), Keinginan (desire), Keyakinan (conviction).

\section{Keputusan Pembelian}

Amirullah (dalam Maghfiroh, 2016) Keputusan pembelian dapat didefinisikan sebagai suatu proses dimana konsumen melakukan penilaian terhadap berbagai alternatif pilihan, dan memilih salah satu atau lebih alternatif yang diperlukan berdasarkan pertimbanganpertimbangan tertentu. Peter dan olson (dalam Sangadji, 2013; Maharani dan Darma, 2018) menyatakan bahwa" inti dari pengambilan keputusan konsumen dalah proses pengintegritasan yang mengombinasikan pengetahuan untuk mengevaluasi dua prilaku atau lebih, dan memilih salah satu diantaranya". Adapun proses pengambilan keputusan yang dilakukan pengunjung terdiri dari lima tahap, yaitu Nurul (dalam Mustikasari, 2017): 1.Pengenalan Kebutuhan, 2. Pencarian Informasi, 3. Evaluasi Alternatif Pilihan, 4. Keputusan Pembelian,5. Perilaku Pasca Pembelian. Perilaku membeli atau keputusan konsumen diawali dengan rangsangan yang kemudian dipengaruhi oleh faktor - faktor lingkungan seperti faktor sosial, budaya, pribadi, psikologi, dan mempengaruhi konsumen dalam pemilihan produk tertentu Kotler (dalam Sangadji, 2013). Pride dan Ferrell (dalam Sangadji, 2013) membagi faktor yang mempengaruhi perilaku konsumen ke dalam tiga kelompok, yaitu : Faktor Pribadi, Faktor psikologis, Faktor social

\section{Kerangka Konseptual}

Penelitian ini nantinya hanya meneliti tentang strategi pemasaran untuk meningkatkan keputusan pembelian pada lokasi penelitian. Digital marketing bisa memberikan input yang cukup kuat bagi konsumen untuk menciptakan minat beli. Nilai hedonik membangun respon konsumen didasarkan pada tingkat respons emosional dan rasional untuk menciptakan minat 
beli. E-Commerce yang menarik dan mudah digunakan akan menimbulkan minat yang tinggi, misalkan seperti E-Word of Mouth, Nilai Hedonik, E- Commerce akan menimbulkan minat yang tinggi. Sehingga keputusan pembelian akan terjadi.

Hal tersebut dapat digambarkan seperti gambar keragka berpikir di bawah ini:

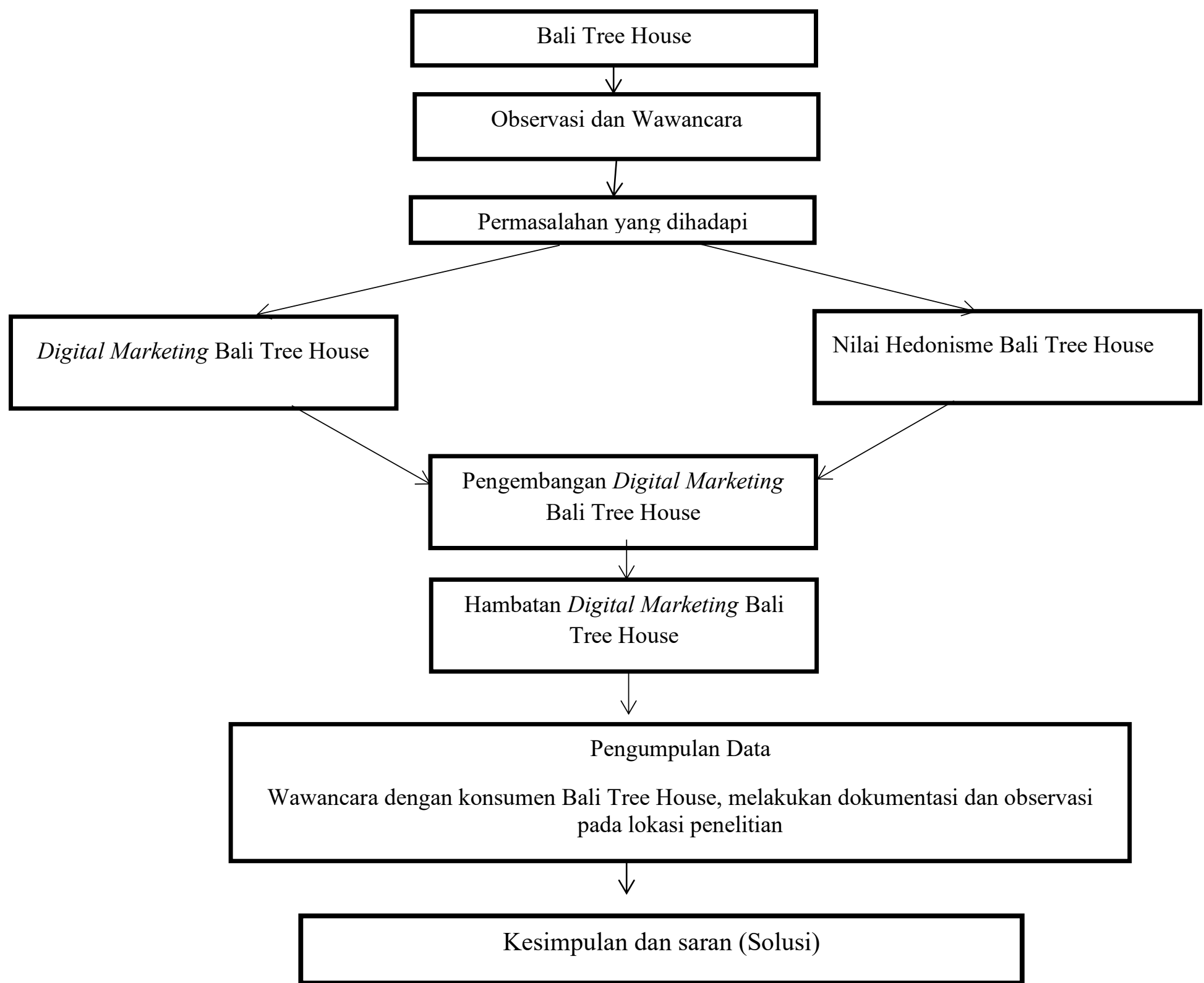

Gambar 2.1 Kerangka Pemikiran

Sumber dikembangkan oleh peneliti 


\section{METODE PENELITIAN}

Desain penelitian pada penelitian ini akan menggunakan pendekatan kualitatif dengan metode analisis deskriptif. Aktivitas pada penelitian ini dicirikan oleh kegiatan pengumpulan data, menggambarkan, dan menafsirkan data tentang situasi yang dialami pada lokasi penelitian Bungin (2007). Penelitian telah dilaksanakan dengan metode kualitatif dengan hasil menemukan dan memahami apa yang ada di balik fenomena yang akan diteliti. Metode kualitatif pada penelitian ini memberikan rincian fenomena yang sulit diungkapkan dalam metode kuantitatif (Darma, 2004).

Penelitian ini dilakukan pada salah satu pondok wisata yaitu pada Bali Tree House yang berada di Jln. Denpasar - singaraja, Desa Baturiti Kaja, Kec. Baturiti, Kab. Tabanan. Bali Tree House dipilih sebagai lokasi penelitian dengan pertimbangan sebagai berikut: Strategi Digital Marketing di Bali Tree House implementasinya masih minim. Judul penelitian yang diangkat penulis sesuai dengan fenomena atau permasalahan yang terjadi di Bali Tree House. Kemudahan dalam mendapatkan sebuah informasi dan data.

Data yang diperlukan dalam penelitian ini diperoleh dengan menggunakan beberapa teknik pengumpulan data yaitu: Observasi, Wawancara, Dokumentasi

Teknik analisis data yang digunakan pada penelitian ini adalah analisis dekriptif kualitatif. Analisis Kualitatif merupakan proses pencarian dan penyusunan data secara sistematis melalui pengamatan langsung di lapangan, wawancara, catatan lapangan, dan bahan lainnya. Data tersebut dianalisis dengan cara mengorganisasikan data, menjabarkan dalam unitunit, melakukan sintesa, menyusun ke dalam pola, memilih mana yang penting dan akan dipelajari, serta membuat kesimpulan yang dapat diceritakan kepada orang lain (Sugiyono, 2013).

Analisis Kualitatif merupakan proses pencarian dan penyusunan data secara sistematis melalui wawancara, catatan lapangan, dan bahan lainnya. Aktivitas dalam analisis kualitatif dilakukan secara interaktif dan berlangsung secara terus menerus sampai tuntas hingga datanya sudah penuh. Analisis data kualitatif dapat digambarkan sebagai berikut: 


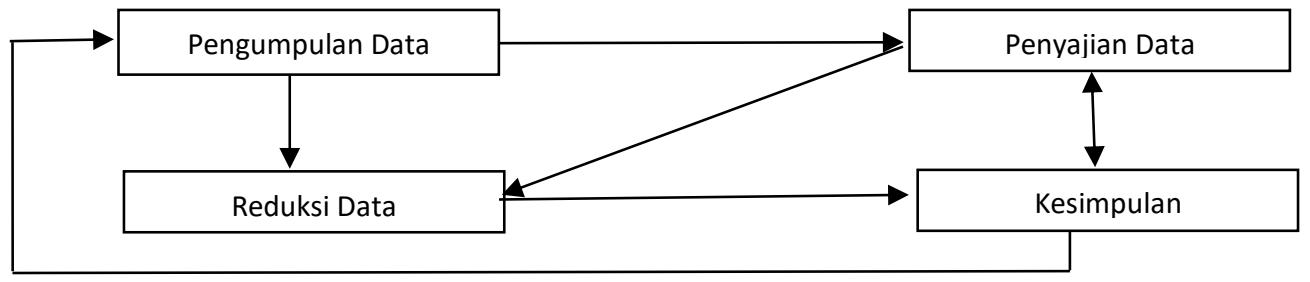

Gambar 3.1: Komponen analisis data.

Sumber: Sugiono, 2013

Langkah-langkah yang dilakukan untuk menganalisis data dalam gambar diatas dapat dijelaskan sebagai berikut: 1, Data Collection atau pengumpulan data merupakan langkah pertama yang dilakukan dalam menganalisis data. Data yang telah dikumpulkan di lapangan dicatat dan diteliti secara rinci. 2. Data Reduction atau merangkum data adalah merangkum hal-hal pokok, memfokuskan pada hal-hal yang penting, dicari tema dan polanya, dengan demikian data yang telah direduksi memberikan gambaran yang lebih jelas dan memudahkan peneliti untuk pengumpulan data selanjutnya. 3. Data Display dalam penelitian kualitatif adalah penyajian data dalam bentuk tabel, grafik, dan sejenisnya. Melalui penyajian data tersebut maka data terorganisasi, tersusun dalam pola hubungan, sehingga semakin mudah untuk dipahami. 4. Conclucion Drawing/Verifying merupakan tahap akhir dalam melakukan analisis data yaitu dengan cara memberikan kesimpulan awal yang masih bersifat sementara. Kesimpulan yang nantinya akan dicapai adalah merupakan temuan baru yang sebelumnya belum pernah ada temuan yang dapat berupa deskripsi atau gambaran suatu objek yang sebelumnya masih remang-remang atau gelap sehingga setelah dilakukan penelitian menjadi lebih jelas.

Pengujian keabsahan data pada penelitian ini menggunakan metode triangulasi yaitu metode pemeriksaan keabsahan data yang memanfaatkan sesuatu yang lain dalam membandingkan hasil wawancara terhadap objek penelitian. Triangulasi yang digunakan pada penelitian ini meliputi triangulasi sumber.

\section{PEMBAHASAN}

Keputusan pembelian merupakan salah satu dari visi dan misi dari suatu organisasi. Di dalam untuk menciptakan Keputusan pembelian tersebut diperlukan suatu identifikasi dan beberapa faktor terlibat. Dengan demikian maka peneliti menganalisis fenomena yang sedang berlangsung. Sehubungan dengan fokus penelitian ini yaitu bagaimana meningkatkan 
keputusan pembelian pada Bali Tree House pertanian dengan memanfaatkan hedonism dan digital marketing.

Hedonism dan digital marketing merupakan beberapa strategi pemasaran yang kerap diterapkan pada era digital 4.0 pada saat ini pemasaran melalui media internet sangat menjadi andalan bagi para pengusaha. Perkembangan teknologi saat ini sangat pesat dan sangat cepat untuk mendapatkan pasar yang diinginkan. Hedonisme merurapakan perilaku yang berhubungan dengan panca indera, khayalan dan emosi yang menjadikan kesenangan dan kenikmatan materi sebagai tujuan utaman hidup, maka Untuk mengetahui bagaimana penerapan dari digital marketing dan hedonisme pada bali tree house maka dibutuhkan informasi terkait dengan website, akomodasi dan media pemasaran lainnya yang digunakan untuk mempromosikan bali tree house.

Pada bagian ini, peneliti ingin menjabarkan beberapa temuan yang berhasil didapatkan di lapangan dari beberapa orang informan yang terlibat secara langsung maupun costumer di Bali Tree House.

\section{Digital Marketing terhadap keputusan pembelian}

Perkembangan teknologi saat ini sangat pesat, perkembangannya sudah mulai merambah kebagian pemasaran. Pengguna internet saat ini sangat banyak jumlahnya diseluruh dunia pada tahun 2018 pengguna internet dunia menjadi 3.600.2 (millions) yang dilansir www.Marketer.com.

Pengusaha diindonesia banyak memanfaatkan kesempatan ini sebagai alat pemasaran. Digital marketing merupakan sebuah media yang digunakan sebagai platform pembangun brand image suatu perusahaan atau produk dan juga mendukung fungsi penjualan terhadap target konsumen. 


\section{Sarana Pemasaran}
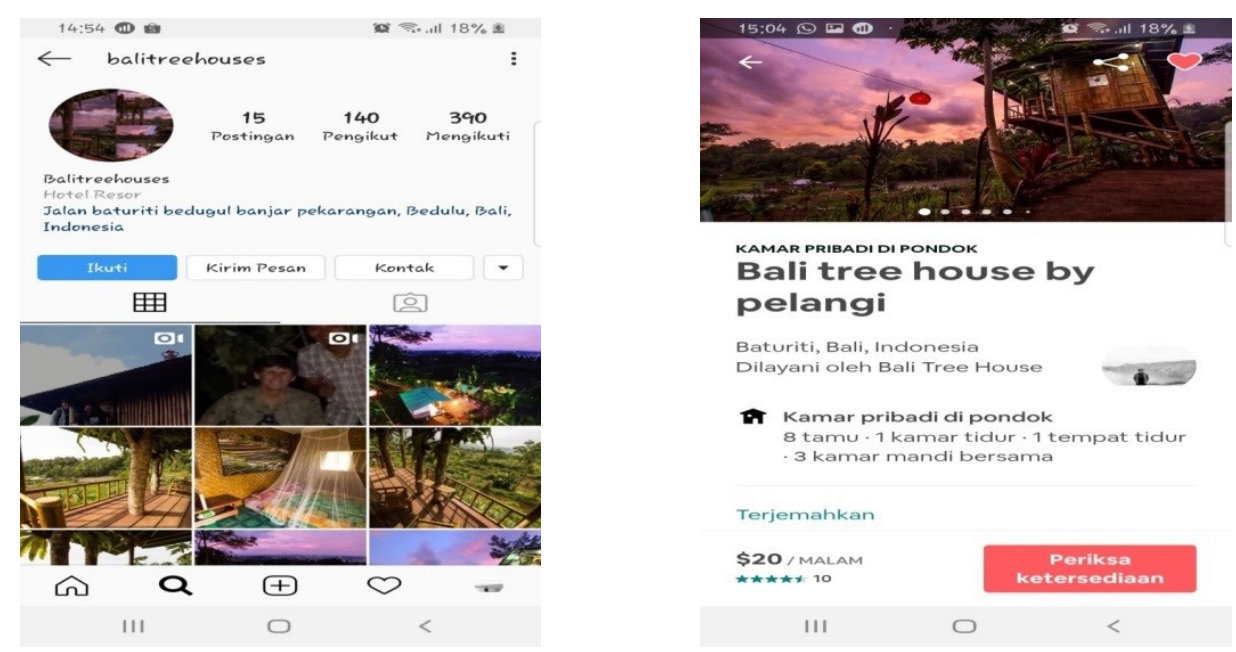

$$
\begin{aligned}
& \text { KAMARPRIBADIDIPONDOK } \\
& \text { Bali tree house by }
\end{aligned}
$$
pelangi

Baturiti, Bali, Indonesia

Dilayani oleh Bali Tree House

- Kamar pribadi di pondok

8 tamu-1 kamar tidur - 1 tempat tidur

3 kamar mandi bersam

Terjemahkan

$\$ 20 /$ MALAM

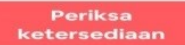

111

Gambar 5.2

Instagram (kiri) dan Airbnb (kanan) Bali Tree House

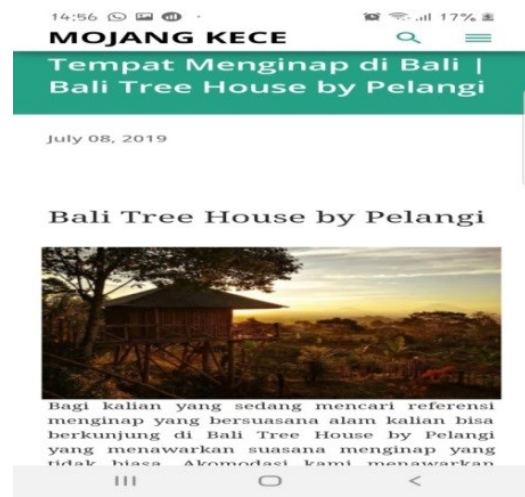

Gambar 5.3

Blog Dari Bali Tree House

Pengaruh E-Commerce terhadap Keputusan Pembelian dapat disimpulkan ECommerce memberikan pengaruh terhadap Keputusan Pembelian dengan adanya e-commerce dapat manfaatkan oleh perusahaan untuk terus berusaha untuk mempertahankan kinerja supaya tidak kalah saing dengan website lainnya Putra (2015). Ditegaskan pula Tujuan dari digital marketing adalah untuk mempertahankan proses komunikasi dengan pelanggan, di mana pelanggan mendapatkan informasi tentang produk, karakteristik, harga dan syarat penjualan. 


\section{Sarana $E-$ Word of Mouth}

Katharina
18-19 Mei $\begin{aligned} & \text { Martyna } \\ & \text { 25-26 Mar } \\ & \text { Nilai Keseluruhan }\end{aligned}$

Gambar 5.4

E - WOM yang terjadi pada E- commerce Airbnb Bali Tree House

E- WOM atau ulasan yang ditinggalkan oleh customer sebelumnya dapat memberikan sebuah gambaran kepada calon customer yang ingin melakukan sebuah pembelian produk maupun jasa. Hal ini ditegaskan oleh Penelitian yang dilakukan oleh Jimenez dan Mendoza dalam Mustikasari (2017), menunjukkan bahwa e-WOM memiliki pengaruh terhadap perilaku konsumen sebelum konsumen memutuskan untuk membeli sebuah produk atau jasa.

\section{Hedonic Terhadap Keputusan Pembelian}

Dari dokumentasi yang saya peroleh ada beberapa tamu yang memberikan respon yang sangat positif dalam chat kepada bapak Rama Putra mengenai bagaimana respon mereka sebelum tiba dan sesudah tiba. Hal ini dipertegas dari hasil dokumentasi:

$\leftarrow$ Rose
Terkonfirmasi
Hey! Can't wait to meet
you and join you in your
beautiful tree house. We will
be travelling up from Ubud
on the 21st - we might need
pick up depending on how
difficult it is to get to you!
speak soon,
Rose \& James
3 mingguyang lalu



Gambar 5.2

Respon yang diberikan customer dimedia digital

Sumber: Airbnb Akun dan diolah peneliti 
Nilai hedonis merupakan suatu kegiatan pembelian yang didorong dengan perilaku yang berhubungan dengan panca indera, khayalan dan emosi yang menjadikan kesenangan dan kenikmatan materi sebagai tujuan utaman hidup. Arnold dan Reynolds (dalam Darma, 2014) menggolongkan motivasi hedonis ke dalam enam kategori, jadi pernyataan diatas sesuai dengan 6 motivasi pembelian secara hedonism.

\section{Keputusan Pembelian Pada Bali Tree House}

Adapun proses pengambilan keputusan yang dilakukan pengunjung terdiri dari lima tahap, yaitu, Pengenalan Kebutuhan, Pencarian Informasi, Evaluasi Alternatif Pilihan, Keputusan Pembelian, Perilaku Pasca Pembelian Nurul (dalam Mustikasari, 2017). Dapat disimpulkan dari pembahasan diatas bahwa dalam proses pengambilan keputusan pembelian bali tree house tidak mengalami kendala.

\section{Faktor Yang Dipertimbangkan Konsumen Dalam Melakukan Pembelian.}

\section{Faktor Psikologis}

Merupakan faktor yang ada pada diri manusia sebagian menetapkan perilaku orang tersebut sehingga mempengaruhi perilaku sebagai konsumen. Faktor ini memiliki beberapa bagian yaitu : motif merupakan adalah kekuatan energy internal yang mengarahkan kegiatan seseorang kearah pemenuhan kebutuhan. Persepsi merupakan proses pemilihan, pengorganisasian, dan interpretasi informasi untu mengahsilkan sebuah makna. Sesuai dengan teori yang dinyatan oleh Kotler (dalam Sangadji, 2013) yang menyatakan bahwa Perilaku membeli atau keputusan konsumen diawali dengan rangsangan yang kemudian dipengaruhi oleh faktor - faktor lingkungan seperti faktor pribadi dan psikologi, dan mempengaruhi konsumen dalam pemilihan produk tertentu.

\section{Faktor Sosial}

merupakan faktor yang mempengaruhi keputusan pembelian berdasarkan lingkungan sekitar dengan demikian, perilaku konsumen juga akan dipengaruhi oleh masyarakat atau faktor sosial yang berada disekitarnya. Salah satu dari faktor sosial adalah kelompok referensi, dengan adanya Word of Mouth perusahaan akan mendapat keuntungan tanpa harus mengeluarkan biaya karena dengan menyebarnya berita baik tentang sebuah produk tersebut maka pembelian akan semakin meningkat sehingga profit perusahaan juga meningkat. 


\section{PENUTUP}

Dari penelitian yang telah dilakukan oleh penulis di Bali Tree House yang menerapkan Strategi digital marketing dan Hedonisme dalam meningkatkan keputusan pembelian yang bertujuan: 1. Untuk mengetahui peranan hedonism dan digital marketing dalam meningkatkan keputusan pembelian pada Bali Tree House. 2. Untuk mengetahui hambatan apa saja yang dialami dalam penggunaan digital marketing untuk meningkatkan keputusan pembelian Bali Tree House. Maka dapat disimpulkan bahwa Bali Tree House sudah menerapkan Strategi digital marketing dan Hedonisme yang tepat untuk meningkatkan keputusan pembelian. Bali Tree House telah memanfaatkan Strategi digital marketing dengan pemanfaatan E - commerce, blog, dan media sosial untuk pengoptimalan pemasaran secara digital. Hedonism yang dikombinasikan dengan digital marketing dengan gambaran visual dapat meningkatkan daya Tarik konsumen.

Dari hasil penelitian ini ada beberapa temuan yang diharapkan dapat dijadikan pertimbangan dalam membuat kebijakan yang berkaitan dengan permasalahan yang di teliti yang berkaitan dengan strategi digital marketing dan hedonism dalam meningkatkan keputusan pembelian yaitu: Membuat kebijakan untuk merancang strategi pemasaran digital marketing dan hedonism yang dapat menyentuh segala faktor - faktor keputusan pembelian agar dapat memaksimalkan pemasaran bali tree house. Membuat kebijakan untuk mengevaluasi pergerakan tren pasar secara lebih tepat guna mendapatkan keunggulan dari para pesaing dalam mempersiapkan strategi - strategi yang tepat dan cepat untuk mengatasi fluktuasi tren yang terjadi pada saat ini. 


\section{DAFTAR PUSTAKA}

Agung, N.F.A., and Darma, G.S. (2019). Opportunities and Challenges of Instagram Algorithm in Improving Competitive Advantage, International Journal of Innovative Science and Research Technology, 4 (1): 743-747.

Aryadi, A.A. (2018). Pengaruh Electronic Word of Mouth pada Situs Web/ Aplikasi Booking Hotel terhadap Citra Merk dan Minat Beli Hotel. Yogyakarta: Universitas Islam Indonesia.

Astuti, K. A., and Darma, G. S. (2019). Community-based tourism: measuring readiness of artificial intelligence on traditional village, International Journal of Social Sciences and Humanities, 3 (3): 81-89.

Bali, I.N.A.P., and Darma, G.S. (2019). Menguji Kesiapan Pengelolaan Desa Berbasis Manajemen Modern Guna Menghadapi Era Revolusi Industri 4.0, Jurnal Manajemen \& Bisnis, 16 (2): 1-13.

Bungin, B. (2007). Penelitian Kualitatif Komunikasi, Ekonomi, Kebijakan Public Dan Ilmu Sosial Lainnya. Jakarta: Prenada Media Group.

Darma, G.S. (2019). Kacamata Media, Kesuksesan Bersyarat. Indonesia: Pustaka Larasan Press.

Darma, G.S., Apollo, A., Rusmanda, G., and Umar, Y. (2019). Digital Education 4.0. Indonesia: Cakra Media Utama Press.

Darma, G.S. (2018). Seuntai Pesan, Menjawab Zaman. Indonesia: Pustaka Larasan Press.

Darma, L.A. (2014). Analisa Pengaruh Hedonic Shopping Value Terhadap Impulse Buying Dengan Shopping Lifestyle Dan Positive Emotion Sebagai Variabel Intervening Pada Mall Ciputra World Surabaya, Jurnal Manajemen Pemasaran, 8 (2). Universitas Kristen Petra. Surabaya.

Darma, G.S. (2004). Qualitative and Quantitative Data in Management Research: A Study of the Banking Industry, Jurnal Ekonomi \& Bisnis, 16 (2): 107-118.

Dewi, M.V.K., and Darma, G.S. (2019). The Role of Marketing \& Competitive Intelligence In Industrial Revolution 4.0, Jurnal Manajemen \& Bisnis, 16 (1): 1-12.

Dewi, C.R., and Darma, G.S. (2014). Website Usability, Satisfaction, Loyalty, Security Perception, Trust, and Word of Mouth in e-Commerce Business, Jurnal Manajemen \& Bisnis, 11 (2): 1-30.

Ferdiana, A.M.K., and Darma, G.S. (2019). Understanding Fintech Through Go-Pay, International Journal of Innovative Science and Research Technology, 4 (2): 257-260. 
Harwindra, Y.P. (2015). Pengaruh Kegiatan Pemasaran Digital Dan Perilaku Online Konsumen Pada Peningkatan Kesadaran Konsumen Dan Dampaknya Terhadap Keputusan Pembelian Via Website.

Mardiani, I.E., dan Orland Jorge Imanuel. (2013). Analisis Keputusan Pembelian Konsumen Melalui Media Online (E-Marketing), Jurnal Ekonomi, 4 (2), November 2013.

Maghfiroh, A. (2016). Pengaruh Citra Merek Terhadap Minat Beli dan Keputusan Pembelian, Jurnal Administrasi Bisnis (JAB), 40 (1). Universitas Brawijaya: Malang.

Maharani, I.G.A.P.D., and Darma, G.S. (2018). Consumer Purchasing Behavior Analysis on Impulse Buying, Jurnal Manajemen \& Bisnis, 15 (3): 16-37.

Moleong, L. J. (2011). Metodologi Penelitian Kualitatif. Bandung: PT Remaja Rosdakarya.

Mustikasari, A. (2017). Pengaruh E-Wom Terhadap Keputusan Berkunjung Ke Tempat Wisata Di Kota Bandung. Bandung: Universitas Telkom.

Naas, M.A. (2016). Pengaruh Iklan Politik Melalui Media Sosial (Facebook) Terhadap Minat Memilih Kepala Daerah Di Kota Samarinda. 4 (3).

Putra, H.P. (2015). Pengaruh Penerapan E-Commerce Terhadap Keputusan Pembelian (Studi Kasus Pada Pengguna Steam Valve), Ecodemica, III. Bandung: Universitas Telkom.

Putra, I.G.N.A.P., and Darma, G.S. (2019). Is Bitcoin Accepted in Indonesia? , International Journal of Innovative Science and Research Technology, 4 (2): 424-430.

Putri, F.C. (2016). Pengaruh Word Of Mouth Terhadap Minat Beli Dan Dampaknya Pada Keputusan Pembelian (Survei Pada Konsumen Legipait Coffeeshop Malang), Jurnal Administrasi Bisnis (JAB), 34 (1).

Poernamawati, D.E. (2018). Analisis Dimensi Electronic Word Of Mouth (Ewom) Dan Pengaruhnya Terhadap Minat Kunjungan Pada Obyek Wisata Di Malang Raya, adbis Jurnal Administrasi dan Bisnis, 12.

Pradiani, T. (2017). Pengaruh Sistem Pemasaran Digital Marketing Terhadap Peningkatan Volume Penjualan Hasil Industri Rumahan.

Pranata, I.M.A., and Darma, G.S. (2014). Strategi Penerapan E-Commerce Dalam Meningkatkan Keunggulan Bersaing, Jurnal Manajemen \& Bisnis, 11 (1): 69-81.

Sangadji, E.M. (2013). Perilaku Konsumen Pendekatan Disertai: Himpunan Jurnal Penelitian. Yogyakarta: ADHI.

Strauss, et all. (2009). E-Marketing $5^{\text {th }}$ Edition. Prientice-Hall, Inc. New Jersey: Upper Saddle. Shahnaz, N.B.F. (2016). Faktor Yang Mempengaruhi Minat Beli Konsumen Di Toko Online. Semarang: Universitas Negeri Semarang. 
Sugiyono. (2013). Metodelogi Penelitian Kuantitatif, Kualitatif Dan R\&D. Bandung: ALFABETA.

Sugiyono. (2017). Metodelogi Penelitian Kuantitatif, Kualitatif Dan R\&D. Bandung: ALFABETA.

Supit, H.A.M., and Darma, G.S. (2018). Aplikasi Mobile Trading Monex Guna Mendukung Customer Relationship Management, Jurnal Manajemen \& Bisnis, 15 (1): 46-60.

Widana, I.W., and Darma, G.S. (2018). Branding Denpasar Smart City Guna Meningkatkan Kunjungan Wisatawan, Jurnal Manajemen \& Bisnis, 15 (1): 176-199.

Widani, N.M., Abiyasa, A.P., Darma, G.S., and Maradona, A.F. (2019). Menguji Ketajaman Implementasi E-Commerce Dalam Penjualan Kamar Hotel di Bali, Jurnal Manajemen \& Bisnis, 16 (2): 79-98. 